\title{
Functional Markers for Red Raspberry
}

\author{
Mary Woodhead', Ailsa Weir, Kay Smith, and Susan McCallum \\ Genetics Department, Scottish Crop Research Institute, Dundee, DD2 5DA, United Kingdom
}

Katrin MacKenzie

Biomathematics and Statistics Scotland, Dundee, DD2 5DA, United Kingdom

Julie Graham

Genetics Department, Scottish Crop Research Institute, Dundee, DD2 5DA, United Kingdom

\begin{abstract}
AdDitional Index words. Rosaceae, Rubus idaeus, linkage map, QTL, synteny
Abstract. Primers to 43 genes, including those involved in the phenylpropanoid and volatile pathways, cell wall, ethylene and polyamine metabolism, and from Prunus linkage group (LG) 6 were tested in red raspberry (Rubus idaeus) cultivars Latham and Glen Moy, and 40 were polymorphic. Thirty-seven genes were subsequently mapped in the 'Latham' $\times$ 'Glen Moy' population and were placed across all seven Rubus LG. This brings to 97 the total number of genic markers mapped in this Rubus mapping population. Fifteen genes are associated with existing quantitative trait loci for ripening, cane diseases, including yellow rust (Phragmidium rubi-idaei), cane botrytis (Botrytis cinerea), spur blight (Didymella applanata), and cane spot (Elsinoe veneta) or fruit color in $R$. idaeus and can be used for identifying bacterial artificial chromosome clones for physical mapping studies. A cluster of four genes from Prunus LG6 mapped together to Rubus LG3, suggesting that there may be sufficient synteny between these Rosaceae over small genomic regions that can be exploited in future studies.
\end{abstract}

Conventional plant breeding in woody perennials like red raspberry is a long and expensive process, in terms of the time required to reach a stage where certain traits can be assessed and the space required to grow the large number of plants generated in a crossing program. In red raspberry, it can take 15 years from the time of the first cross to the release of a new cultivar (Graham and Jennings, 2009). Advances in molecular genetics, in particular, the development of molecular markers, have the potential to speed up plant breeding by permitting the selection of seedlings with desirable characteristics at a much earlier stage. However, this approach requires the generation of reliable molecular tools such as markers, linkage maps, DNA sequences, and quantitative trait loci (QTL) that can be employed within traditional plant breeding programs.

Phylogenetic analyses divide the Rosaceae into three subfamilies, Dryadoideae, Rosoideae, and Spiraeoideae (Potter et al., 2006). Commercially, the Spiraeoideae, which includes the perennial tree crops apple (Malus $\times$ domestica), peach (Prunus persica), cherry (Prunus avium and Prunus cerasus), plum (Prunus domestica and Prunus salicina), apricot (Prunus armeniaca), almond (Prunus dulcis), and pear (Pyrus communis), and the Rosoideae, which includes raspberry ( $R$. idaeus), strawberry (Fragaria $\times$ ananassa), and ornamentals (e.g., Rosa spp.), are the most important. Considerable progress has been made in generating the genetic knowledge and tools necessary for markerassisted breeding in these Rosaceae crops (Shulaev et al., 2008). The peach genome sequence was recently released (International Peach Genome Initiative, 2010), and sequencing of the apple (Han et al., 2009) and woodland strawberry (Fragaria vesca) (Shulaev et al., 2010) genomes is underway. These genome

Received for publication 25 May 2010. Accepted for publication 30 June 2010. We thank Clare Booth and Louise Donnelly for sequencing and genotyping assistance, Linda Cardle for establishing the Rubus sequence database, Luke Ramsay and Rex Brennan for critical reading of the manuscript, and the Scottish Government for funding this work.

${ }^{1}$ Corresponding author. E-mail: Mary.Woodhead@scri.ac.uk. sequences will prove valuable resources for comparative mapping in other Rosaceae. Considerable synteny exists between Malus and Prunus (Dirlewanger et al., 2004) and also between Fragaria and Prunus, although the extent of colinearity is variable (Vilanova et al., 2008). It would be expected that comparative mapping between Rubus and Prunus should also be possible, providing a means to identify genes in regions of the red raspberry genome currently populated by largely anonymous markers.

Phenotypic traits and molecular tools are established in $R$. idaeus, with the development of genetic linkage maps (Graham et al., 2004, 2006; McCallum et al., 2010; Pattison et al., 2007; Woodhead et al., 2008) and the identification of QTL for important traits. These include resistance to cane diseases e.g., cane spot, spur blight, cane botrytis, and yellow rust (Graham et al., 2006), phytophthora root rot (Phytophthora fragariae var. rubi) (Pattison et al., 2007; J. Graham, K. Smith, I. Tierney, M. Woodhead, and C. Hackett, unpublished data), large raspberry aphid (Amphorophora idaei) resistance (Sargent et al., 2007a), fruit anthocyanin content (Kassim et al., 2009), cane height, time to fruit ripening (Graham et al., 2009), and fruit color and quality attributes (McCallum et al., 2010). More importantly, marker-assisted breeding is already being used for the identification of cultivars and breeding selections with reduced susceptibility to phytophthora root rot and cane diseases (J. Graham, K. Smith, and N. Jennings, unpublished data). For some of the important Rubus traits already identified, there are no candidate genes underlying the QTL, and identifying relevant bacterial artificial chromosome (BAC) clones for physical mapping in these regions is more difficult. Progress would be greatly enhanced if further expressed sequence tags (ESTs) or EST-simple sequence repeats (SSRs) (EST-SSRs) and genes were added to the map, particularly because they tend to be more transferable (Gasic et al., 2008; Sargent et al., 2006, 2007b) and ultimately more useful in marker-assisted breeding, as they are associated with functional genes.

The aim of this study was to add new gene-based markers to the red raspberry genetic linkage map and determine if they 
associate with known QTL. ESTs and genes involved in metabolic pathways influencing fruit quality, ripening, and general metabolism were primarily sourced from Rubus, but genes were also identified from the Rosaceae linkage and transcript maps \{mainly the 'Texas' almond $\times$ 'Early Gold' peach [T $\times$ E (2004)] linkage map (Aranzana et al., 2003; Dirlewanger et al., 2004; Horn et al., 2005; Joobeur et al., 1998; Lalli et al., 2005)\}. A cluster of four Prunus ESTs was included to assess whether it may be possible to use data from Prunus to map genes to tight regions in Rubus.

\section{Materials and Methods}

Plant material and DNA isolation. The mapping population used consists of a full sib family generated from a cross between the European red raspberry cultivar Glen Moy and the North American red raspberry cultivar Latham (Graham et al., 2004, 2006). These cultivars differ in a number of key traits, including resistance to various diseases and phenological traits such as dormancy requirement and fruit development. Parents and 330 individuals were planted at three field locations with two open-field sites and one under protection (polytunnel), in randomized complete block trials with three replicates and two plant plots at all locations. DNA was isolated from the parents and 188 progeny (Graham et al., 2003).

Candidate LOCI. Genes involved in traits of interest, including phenylpropanoid content, cell wall modification, ethylene/polyamine metabolism, volatile biosynthesis, protein degradation, and programmed cell death, were identified. GenBank and the Scottish Crop Research Institute (SCRI) Rubus EST database were mined for the candidate ESTs for primer design. Where no Rubus ESTs were available for traits of interest, sequence alignments were performed using genes from other members of the family Rosaceae and primers were designed to conserved regions using Primer 3 (Rozen and Skaletsky, 2000). The genes and primer sequences are shown in Table 1.

In addition, Prunus LG6 was chosen as a source of candidate genes because QTL and markers relating to fruit color and quality (including fresh weight and soluble solid content) map to this region (Dirlewanger et al., 1999; Etienne et al., 2002; Ogundiwin et al., 2009). In Rubus, QTL for fruit color have been identified (McCallum et al., 2010) and a marker for this trait locates close to the map position of a gamma tonoplast intrinsic protein (Tip1), and two membrane intrinsic proteins (Mip2 and Mip3) on LG2. At the nucleotide level, the Rubus Tip1 gene fragment is $80 \%$ identical [Expect $(\mathrm{E})$ value $=6 \mathrm{e}-58$ ] to the Prunus Tip1 gene (AF367456) and the Rubus Mip2 and Mip3 gene fragments are $88 \%(E$ value $=3 e-94)$ and $79 \%(E$ value $=$ 9e-70) identical to the corresponding Prunus genes (GenBank accession numbers AF36748 and AF367460), respectively.

BLASTN searches (Altschul et al., 1997) were performed using the 64 EST markers placed on LG6 of the almond $\times$ peach $[\mathrm{T} \times \mathrm{E}(2004)]$ linkage map found at the Genome Database for the Rosaceae (GDR) (Jung et al., 2004) against in-house $R$. idaeus sequence databases. Nine Prunus ESTs hit $R$. idaeus sequences, and primers were designed to the $R$. idaeus sequences that were most similar to the Prunus ESTs using Primer 3 (Table 2). In addition, primers were designed to six genes and ESTs that mapped to LG6 in the $\mathrm{T} \times \mathrm{E}(2004)$ population or were identified from linkage groups in strawberry (Sargent et al., 2007b; Vilanova et al., 2008) that appeared to be syntenic to Prunus LG6.

Amplification of CANDidate LOCI. Polymerase chain reactions (PCRs) were performed using the 'Latham' and 'Glen
Moy' DNA prepared as described in Graham et al. (2003). A typical PCR reaction contained $25 \mathrm{ng}$ of template DNA, $1.0 \mu \mathrm{M}$ primer, $0.2 \mathrm{~mm}$ dNTPs, and 0.1 unit of Taq polymerase (Roche Diagnostics, Burgess Hill, UK) and amplification was performed on a GeneAmp 9700 PCR System Thermal Cycler (Applied Biosystems, Foster City, CA) using a touchdown protocol of 5 min at $94{ }^{\circ} \mathrm{C}$; seven cycles of $30 \mathrm{~s}$ at $94^{\circ} \mathrm{C}, 30 \mathrm{~s}$ at $65^{\circ} \mathrm{C}$, and 30 s at $72{ }^{\circ} \mathrm{C}$ decreasing to $58^{\circ} \mathrm{C}$ at $1{ }^{\circ} \mathrm{C}$ per cycle, followed by 25 cycles of $30 \mathrm{~s}$ at $94^{\circ} \mathrm{C}, 30 \mathrm{~s}$ at $58^{\circ} \mathrm{C}$ and $30 \mathrm{~s}$ at $72{ }^{\circ} \mathrm{C}$, followed by $7 \mathrm{~min}$ at $72^{\circ} \mathrm{C}$ (Woodhead et al., 2003), or an SSR program (Graham et al., 2002).

Single-banded PCR products were treated with Exosap IT (USB Corp., Cleveland) according to the manufacturer's instructions and were sequenced with the same primers used for PCR using the BigDye ${ }^{\circledR}$ Terminator v3.1 Cycle Sequencing Kit (Applied Biosystems) and 25 sequencing cycles of $96{ }^{\circ} \mathrm{C}$ for $10 \mathrm{~s}, 50^{\circ} \mathrm{C}$ for $5 \mathrm{~s}$ and $60^{\circ} \mathrm{C}$ for $4 \mathrm{~min}$ on a GeneAmp $9700 \mathrm{PCR}$ System Thermal Cycler. PCR products from ERubLR_SQ8. 2_D06, RiTerp Synth (terpene synthase), ERubLR_SQ1F_C22, and RiCellulase were cloned into pGEMT Easy (Promega, Southampton, UK) and plasmid DNA was sequenced using universal M13 forward and reverse primers as described elsewhere (Woodhead et al., 2008).

For all DNA sequencing, sequences were determined using a 3730 DNA Analyzer (Applied Biosystems) and data were analyzed manually using Sequencher 4.5 (DNA Codes Corp., Ann Arbor, MI) to identify sequence polymorphisms between 'Latham' and 'Glen Moy'. Where single nucleotide polymorphisms (SNPs) were confirmed, PCRs were repeated on 188 individuals of the mapping population and sequenced as described above or using a Pyrosequencing ${ }^{\circledR}$ assay according to the manufacturer's protocol (Qiagen, Crawley, UK) using a PSQ96MA Pyrosequencing ${ }^{\circledR}$ instrument (Qiagen). Sequence results were obtained in the form of pyrograms and were analyzed using PSQ96MA 2.1 software (Qiagen). For sequences containing SSRs or insertions/deletions (indels), one primer was fluorescently end-labeled and the PCRs were performed on the mapping population, analyzed on an ABI 3730 capillary sequencer (Applied Biosystems), and the data analyzed using the Genemapper software (Applied Biosystems) as described elsewhere (Woodhead et al., 2008). The size polymorphism in ERubLR_SQ10.2_H07 was scored on 1\% agarose gels.

Mapping ANALYSis. Sequence polymorphisms in 40 genes were scored in the 188 individuals and added to the genetic linkage map of Graham et al. (2009) using JoinMap 3 (Van Ooijen and Voorrips 2001). Linkage groups were separated initially at a logarithm (base 10) of odds (LOD) score of 10.0 to 6.0 and map distances were calculated using the Kosambi mapping function.

\section{Results and Discussion}

Polymorphism AND MAPPING. Of the 43 genes investigated, Rubus ESTs were found to 28 sequences (Table 1), and the remaining 15 were amplified by designing primers to multiple alignments of genes from the literature or using primers designed to strawberry sequences (Table 2) that have been mapped in strawberry and the $\mathrm{T} \times \mathrm{E}$ (2004) population (Vilanova et al., 2008). BAC Ri25D10 has been partially sequenced and contains a transparent testa glabra 1(TTG1)like gene that encodes a WD40 domain protein [GenBank accession number HM579852 (M. Woodhead, unpublished data)] and an SSR close to a putative $60 \mathrm{~S}$ ribosomal protein 


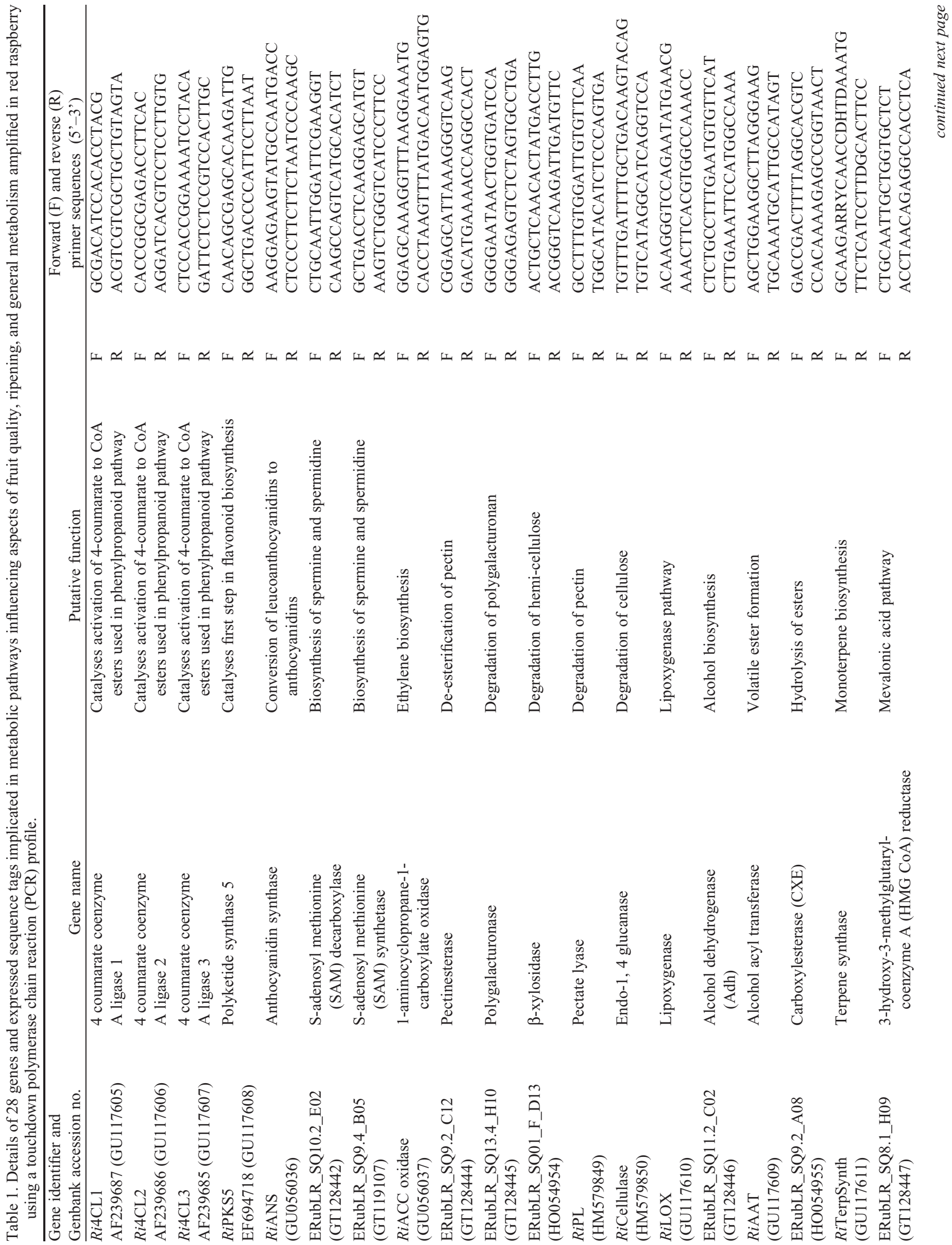




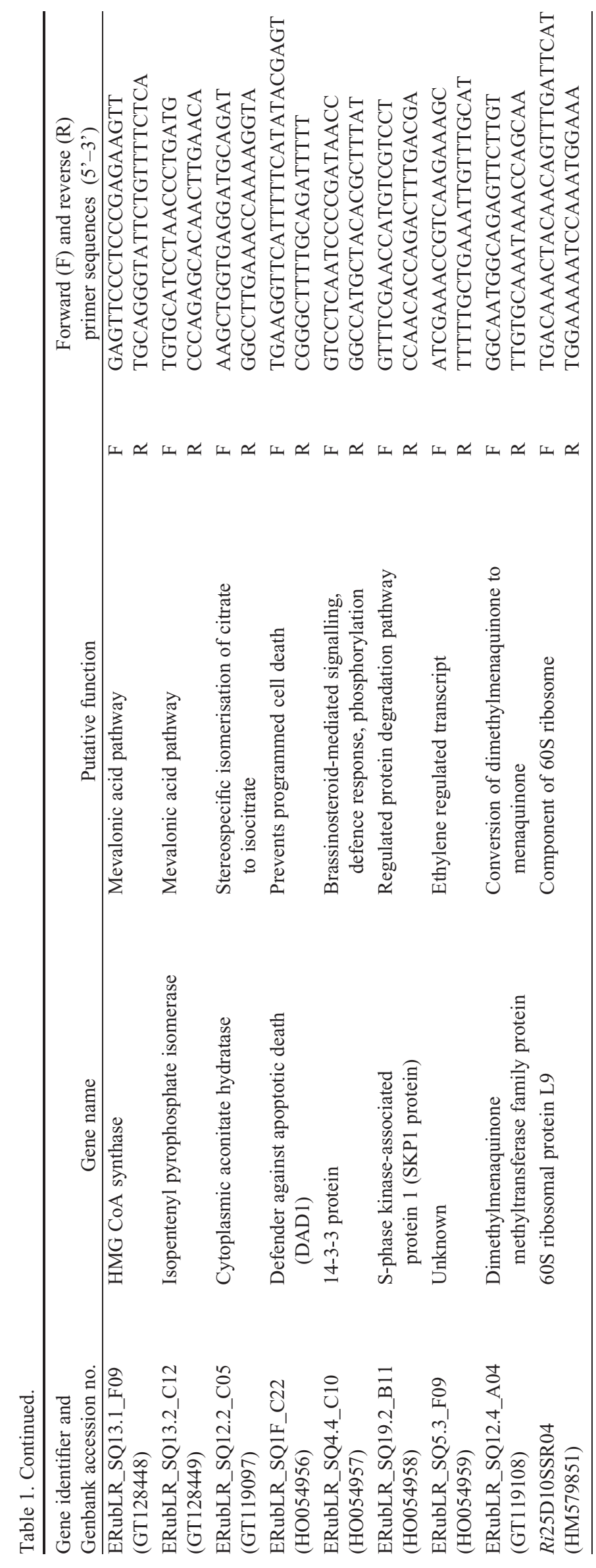

L9 gene (Ri25D10_SSR04), $3.8 \mathrm{~kb}$ away from one end of the BAC was used for mapping purposes (Table 1).

Of the 43 genes identified, ERubLR_SQ13.2_D09 failed to amplify, while ERubLR_SQ8.4_B06 and ERubLR_SQ6.2 D07 yielded multibanded PCR products and all three were discarded. The remaining 40 polymorphic sequences consisted of 30 SNPs and 10 size polymorphisms, one of which was an SSR (Table 3).

MAPPING. All but three of the 40 polymorphic markers were mapped as shown in Table 3 and Fig. 1. RiPGLM (phophoglucomutase precursor) exhibited severe segregation distortion (chi-square of 13.7 with $1 \mathrm{df}$ ). RiANS (anthocyanidin synthase) and RiLOX (lipoxygenase) in which the SNPs were scored, segregated in the expected 1:1 ratio and could not be located on the linkage map, as they showed only weak linkages to other markers, with no LOD scores greater than three. Both genes are heterozygous in 'Glen Moy' and homozygous in 'Latham', which is unusual for this population where 'Latham' is the more heterozygous parent. As a result, there are regions of the 'Glen Moy'-derived parental genetic map where marker coverage is minimal, and these genes may be located in one of these. For the most part, the genes are spread across each linkage group as shown in Fig. 1, but one cluster of four markers derived from Prunus LG6 was observed between 15.2 and $21.8 \mathrm{cM}$ on Rubus LG3 (Table 3), which are located at the distal end of Prunus LG6, between 74.2 and $79.6 \mathrm{cM}$ (Table 2).

Four new markers were placed on LG1, two of which are potential candidate genes for secondary metabolism, including fruit color. BAC Ri25D10 has been mapped using the Ri25D10_SSR04 marker, which lies close to a 60S ribosomal protein L9 (Tables 1 and 3). The BAC also contains a TTG1like gene, which encodes a WD40 domain protein thought to act as a scaffold for MYB and basic helix-loop-helix (bHLH) transcription factors. These proteins can be involved in many processes, including epidermal cell differentiation and anthocyanin production (Serna and Martin, 2006). The 4 coumarate coenzyme A ligase 3 (Ri4CL3) gene located $\approx 3 \mathrm{cM}$ away from this SSR has been suggested to be involved in fruit flavonoid or flavor (Kumar and Ellis, 2003). In addition to anthocyanin pigments, red raspberry fruit contain many other flavonoid and phenolic components, including kaempferol, quercetin, myricetin, $p$-coumaric acid, caffeic acid, ferulic acid, $p$-hydroxybenzoic acid, and ellagic acid (Hakkinen et al., 1999). QTL for fruit pigment and color have already been established on LG1. A bHLH gene underlies a QTL for anthocyanin pigments (Kassim et al., 2009) and the allele status of this gene influences the levels of cyanidin-3-glucoside and cyanidin-3sophoroside pigments in red raspberry (McCallum et al., 2010). The aquaporin gene (ERubLR_SQ10.2_H07) also lies within this fruit quality QTL and will be useful for identifying BACs in this region.

Of the six new genes placed on LG2, two are involved in volatile production, $R i$ TerpSynth (terpene synthase, with similarity to linalool/nerolidol synthase 1 from Antirrhinum majus) and alcohol acyltransferase (RiAAT), which synthesizes ester compounds. Fruit volatile compounds in the red raspberry mapping population are being examined and a similar approach in grape (Vitis vinifera) demonstrated that a gene encoding 1-deoxy-D-xylulose 5-phosphate synthase (DXS) underlies a major QTL for the content of three monoterpene compounds (Battilana et al., 2009). The RiAAT gene lies within ripening QTL (Graham et al., 2009) and in a region populated by 


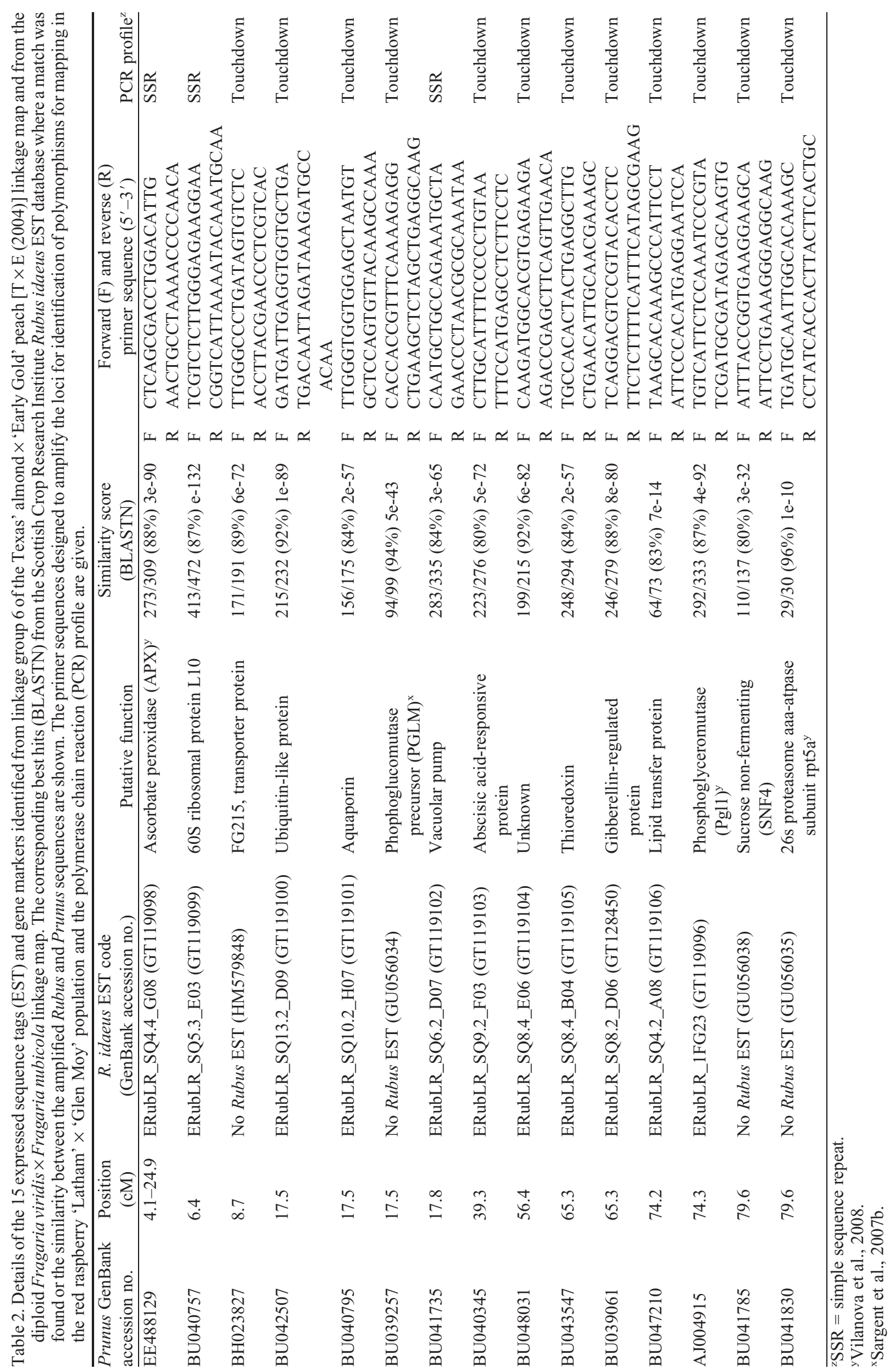




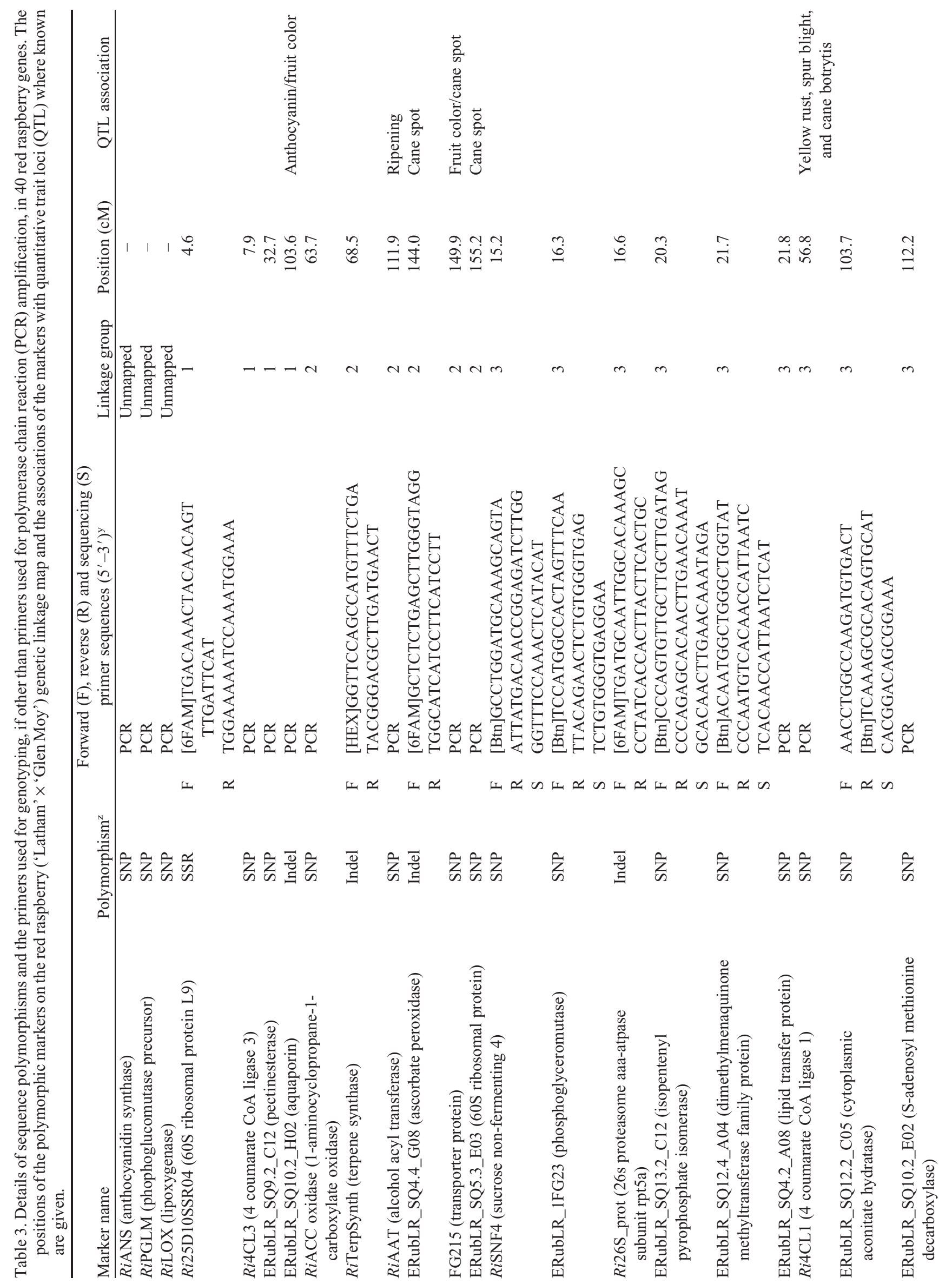




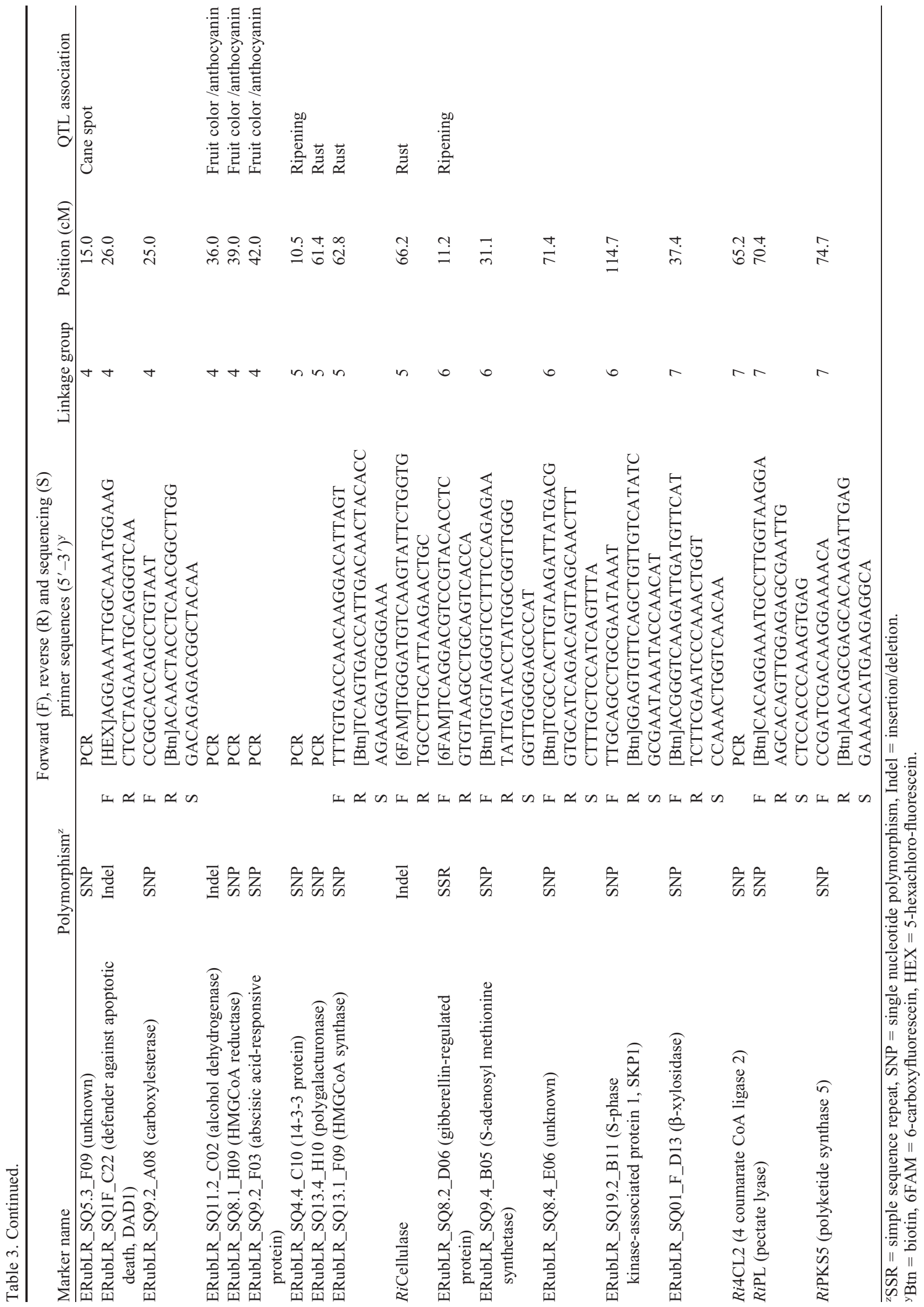




\section{1}

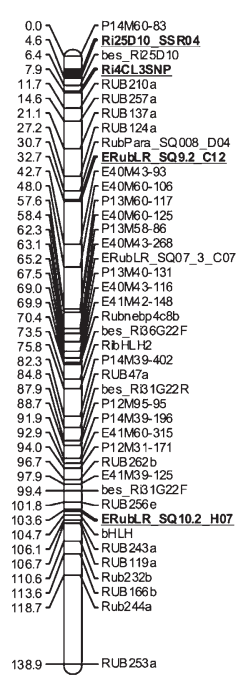

2

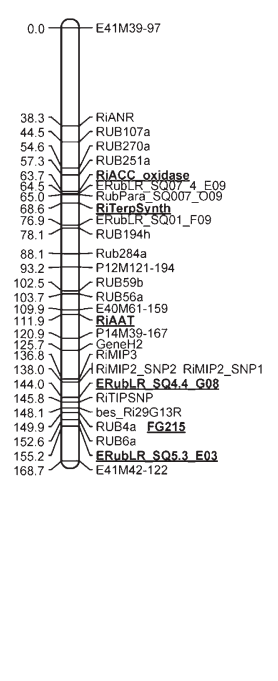

3

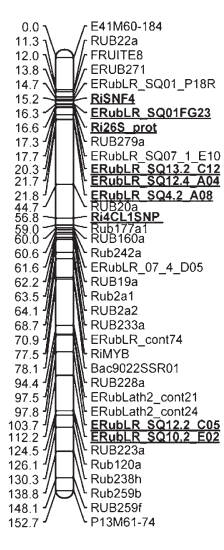

4

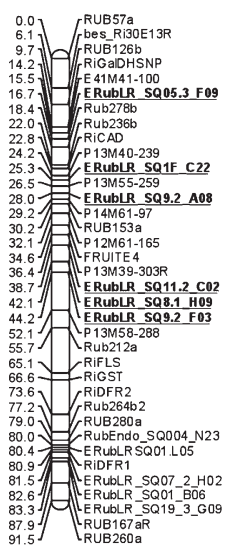

5

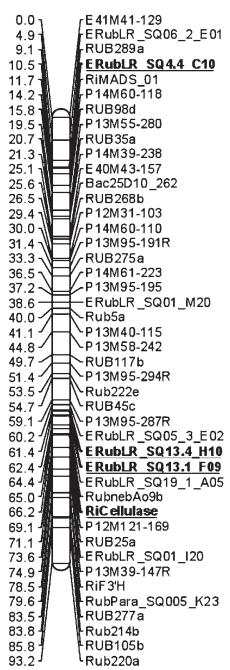

6

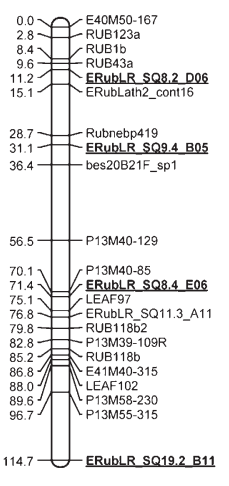

7

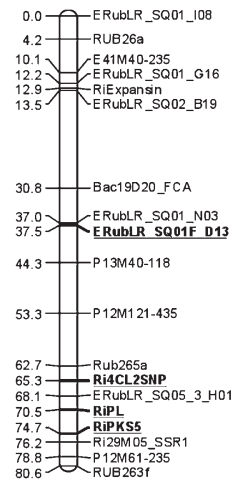

Fig. 1. Genetic linkage map of red raspberry ('Latham' $\times$ 'Glen Moy') showing the new gene markers (underlined and in bold) on each linkage group (LG).

amplified fragment length polymorphism (AFLP) markers, therefore it will prove valuable as a means of identifying BACs to cover this region. In addition, because pathways of volatile production are likely to be similar in green tissues, these genes may also be relevant for examining compounds produced by split and wounded canes, which are then subject to infestation by cane midge (Resseliella theobaldi), and can lead to cane damage and losses in yield of up to $50 \%$ in the following year (Hall et al., 2009). Wounded red raspberry canes have been shown to release a range of related monoterpene compounds, including linalool and geraniol, and also esters (Shepherd et al., 2009).

Ethylene regulates many processes, including the wound response and fruit ripening (Lin et al., 2009), and some genes in volatile biosynthetic pathways (Schaffer et al., 2007). A gene encoding 1-aminocyclopropane-1-carboxylate (RiACC) oxidase, which catalyzes the final step in ethylene biosynthesis, also maps to LG2, but is not associated with ripening QTL (Graham et al., 2009). Ascorbate peroxidase (ERubLR_SQ4.4 G08), 60S ribosomal protein L10 (ERubLR_SQ5.3_E03), and FG215, which all locate to LG6 in Prunus (Table 2), are associated with QTL for ripening (Graham et al., 2009), fruit color (McCallum et al., 2010), and also cane spot resistance (Graham et al., 2006).

Nine additional genes located to LG3 in R. idaeus (Table 3) and are shown in Fig. 1. Of these, the order of a cluster of markers, including lipid transfer protein 2 (Ltp2; ERubLR SQ4.2_A08), phosphoglyceromutase (Pgl1; ERubLR_1FG23), sucrose non-fermenting 4 (SNF4), and 26s proteosome aaaatpase subunit rpt5a, corresponds to the order observed on LG6 in Prunus (Table 2). No Rubus QTL are associated with the genes at present, but in Prunus, this region is associated with QTL for sucrose and soluble solid content (Etienne et al., 2002) and this is currently being investigated in Rubus (D. Zait, personal communication). The Ri4CL1 gene on LG3 has been suggested to have a role in the biosynthesis of phenolics in leaves (Kumar and Ellis, 2003) and is associated with QTL for resistance to yellow rust, spur blight, and cane botrytis (Graham et al., 2006). Aconitate hydratase (ERubLR_SQ12.1_C05), an enzyme involved in the Krebs cycle, and ERubLR_SQ10.2_E02, which encodes a gene for S-adenosyl methionine decarboxylase (SAMDC), involved in polyamine/ethylene synthesis, locate at the distal end of this linkage group and do not colocate with any phenotypic traits at present.

On LG4, ERubLR_SQ5.3_F09, which encodes a putative multibridging factor protein, lies close to a QTL for cane spot resistance (Graham et al., 2006) and genes involved in volatile biosynthesis [alcohol dehydrogenase (Adh) and 3-hydroxy-3methylglutaryl-coenzyme A (HMGCoA) reductase] are associated with QTL for anthocyanin pigments (Kassim et al., 2009) and visual fruit color (McCallum et al., 2010). A MADs-box gene colocated with a ripening QTL on LG5 (Graham et al., 2009), and ERubLR_SQ4.4_C10, encoding a 14-3-3 protein, locates close to the MADs-box gene. These ubiquitous eukaryotic proteins have roles in diverse processes such as cell signaling, cell division, transcription, metabolism (Roberts and de Bruxelles, 2002), and ripening (Goulao and Oliveira, 2007). Two cell wall hydrolases, polygalacturonase (ERubLR_SQ13.4 $\mathrm{C} 10)$ and $R i$ Cellulase, are located on this linkage group, as well as HMGCoA synthase (ERubLR_SQ13.1_F09), which is involved in the mevalonate pathway and is implicated in volatile biosynthesis (Schaffer et al., 2007). All three genes are associated with QTL for rust resistance (Graham et al., 2006).

Four new genes mapped to LG6 and ERubLR_SQ8.4_D06, encoding a gibberellin-regulated protein, lies close to a ripening QTL (Graham et al., 2009). Of the new genes on linkage group seven, two are involved in cell wall metabolism, pectate lyase and $\beta$-xylosidase (ERubLR_SQ01_F_D13). The Ri4CL2 gene has been suggested to be involved in cane lignification (Kumar and Ellis, 2003), and a polyketide synthase 5 (RiPKS5) gene (Zheng and Hrazdina, 2008) locates close to BAC 29M05 SSR1, which contains a PKS1 gene (Kassim et al., 2009). Like the PKS1 gene, RiPKS5 is also a chalcone synthase (Zheng and Hrazdina, 2008), and the proximity of these genes on this linkage group may indicate a cluster of PKS, and perhaps other genes, involved in the phenylpropanoid pathway. In certain fungi and plants, clusters of genes involved in secondary metabolism have been reported (Qi et al., 2004; Novakova et al., 2002), including PKS-like genes (Khaldi et al., 2008). Zheng and Hrazdina (2008) examined the transcript profiles of 
PKS1, PKS4 (encoding a benzaloacetone synthase), and PKS5 genes in raspberry. RiPKS1 gene transcripts accumulated during fruit ripening, suggesting this gene is involved in anthocyanin accumulation. In contrast, the transcript level of RiPKS5 was much weaker during ripening, suggesting the RiPKS5 gene may play a different role in raspberry. However, neither PKS gene is associated with QTL for the major anthocyanin pigments or measures of color in red raspberry fruit (Kassim et al., 2009; McCallum et al., 2010).

Genomics tools and physical mapping for accelerated breeding are less advanced in $R$. idaeus than other members of the Rosaceae such as apple (Han et al., 2007, 2009) and Prunus (Zhebentyayeva et al., 2008). The Rubus 'Latham' × 'Glen Moy' genetic linkage map contains predominantly anonymous AFLP and SSR markers and until now, only 60 gene-based markers. The addition of these new Rubus ESTs and genic markers to the genetic map and the association of 15 with traits of commercial and phenotypic importance (Table 3) will act as useful points of reference in the development of linkage maps in new red raspberry mapping populations. They will also facilitate the identification of BAC clones for targeted genome sequencing.

Rubus genomics will benefit from comparative mapping and sequencing data from other members of the Rosaceae. Twelve of the 40 polymorphic markers were identified from comparative mapping data, primarily LG6 from the Prunus $\mathrm{T} \times \mathrm{E}$ (2004) map, due to evidence of synteny between this group and LG2 in Rubus. Two markers identified at the top of Prunus LG6 locate to Rubus LG2 and four from the bottom of Prunus LG6 map to Rubus LG3. Prunus LG6 was reported to result from a reciprocal translocation event between LG6 and LG8 (Jáuregui et al., 2001), which may explain the division of the markers between these two Rubus linkage groups.

\section{Conclusion}

The addition of 37 gene-based markers to the Rubus linkage map provides further tools for marker-assisted breeding and for identifying clones from the red raspberry BAC library (Hein et al., 2005) for physical mapping. BAC sequencing in regions associated with important traits, including phytophthora root rot and Gene H (J. Graham, K. Smith, M. Woodhead, and A. Weir, unpublished) is already underway and the association of 15 of these gene-based markers with QTL for ripening, fruit quality, and cane diseases will allow further progress in this area. Combined with large-scale transcriptome and high throughput SNP analyses, large numbers of Rubus ESTs will be added to the linkage map in the future. With continued phenotyping of traits of interest and genome sequencing, this information will be available for marker-assisted breeding, to develop highquality cultivars for sustainable fruit production.

\section{Literature Cited}

Altschul, S.F., T.L. Madden, A.A. Schäffer, J. Zhang, Z. Zhang, W. Miller, and D.J. Lipman. 1997. Gapped BLAST and PSI-BLAST: A new generation of protein database search programs. Nucleic Acids Res. 25:3389-3402.

Aranzana, M.J., J. Carbo, and P. Arús. 2003. Microsatellite variability in peach [Prunus persica (L.) Batsch]: Cultivar identification, marker mutation, pedigree inferences and population structure. Theor. Appl. Genet. 106:1341-1352.

Battilana, J., L. Costantini, F. Emanuelli, F. Sevini, C. Segala, S. Moser, R. Velasco, G. Versini, and M.S. Grando. 2009. The 1-deoxyd-xylulose 5-phosphate synthase gene co-localizes with a major QTL affecting monoterpene content in grapevine. Theor. Appl. Genet. 118: 653-669.

Dirlewanger, E., E. Graziano, T. Joobeur, F. Garriga-Calderé, P. Cosson, W. Howad, and P. Arús. 2004. Comparative mapping and marker-assisted selection in Rosaceae fruit crops. Proc. Natl. Acad. Sci. USA 101:9891-9896.

Dirlewanger, E., A. Moing, C. Rothan, L. Svanella, V. Pronier, A. Guve, C. Plomion, and R. Monet. 1999. Mapping QTLs controlling fruit quality in peach (Prunus persica (L.) Batsch). Theor. Appl. Genet. 98:18-31.

Etienne, C., C. Rothan, A. Moing, C. Plomion, C. Bodenes, L. Svanella-Dumas, P. Cosson, V. Pronier, R. Monet, and E. Dirlewanger. 2002. Candidate genes and QTLs for sugar and organic acid content in peach [Prunus persica (L.) Batsch]. Theor. Appl. Genet. 105:145-159.

Gasic, K., Y. Han, S. Kertbundit, V. Shulaev, A.F. Iezzoni, E.W. Stover, R.L. Bell, M.E. Wisniewski, and S.S. Korban. 2008. Characteristics and transferability of new apple EST-derived SSRs to other Rosaceae species. Mol. Breed. 23:397-411.

Goulao, L.F. and C.M. Oliveira. 2007. Molecular identification of novel differentially expressed mRNAs up-regulated during ripening of apples. Plant Sci. 172:306-318.

Graham, J., C. Hackett, K. Smith, M. Woodhead, I. Hein, and S. McCallum. 2009. Mapping QTL for developmental traits in raspberry from bud break to ripe fruit. Theor. Appl. Genet. 118:1143-1155.

Graham, J. and S.N. Jennings. 2009. Raspberry breeding, p. 233-248. In: S.M. Jain and M. Priyadarshan (eds.). Breeding tree crops. IBH \& Science Publication, Oxford, UK.

Graham, J., B. Marshall, and G.R. Squire. 2003. Genetic differentiation over a spatial environmental gradient in wild Rubus idaeus populations. New Phytol. 157:667-675.

Graham, J., K. Smith, K. Mackenzie, L. Jorgensen, C.A. Hackett, and W. Powell. 2004. The construction of a genetic linkage map of red raspberry (Rubus idaeus subsp. idaeus) based on AFLPs, genomicSSR and EST-SSR markers. Theor. Appl. Genet. 109:740-749.

Graham, J., K. Smith, I. Tierney, K. Mackenzie, and C. Hackett. 2006. Mapping gene $\mathrm{H}$ controlling cane pubescence in raspberry and its association with resistance to cane botrytis and spur blight, rust and cane spot. Theor. Appl. Genet. 112:818-831.

Graham, J., K. Smith, M. Woodhead, and J.R. Russell. 2002. Development and use of simple sequence repeat SSR markers in Rubus species. Mol. Ecol. Notes 2:250-252.

Hakkinen, S., M. Heinonen, S. Karenlampi, H. Mykkanen, J. Ruuskanen, and R. Torronen. 1999. Screening of selected flavonoids and phenolic acids in 19 berries. Food Res. Int. 32:345-353.

Hall, D.R., D.I. Farman, J.V. Cross, T.W. Pope, T. Ando, and M. Yamamoto. 2009. (S)-2-acetoxy-5-undecanone, female sex pheromone of the raspberry cane midge, Resseliella theobaldi (Barnes). J. Chem. Ecol. 35:230-242.

Han, Y., K. Gasic, B. Marron, J.E. Beever, and S.S. Korban. 2007. A BAC-based physical map of the apple genome. Genomics 89:630637.

Han, Y.P., D. Chagne, K. Gasic, E.H.A. Rikkerink, J.E. Beever, S.E. Gardiner, and S.S. Korban. 2009. BAC-end sequence-based SNPs and bin mapping for rapid integration of physical and genetic maps in apple. Genomics 93:282-288.

Hein, I., S. Williamson, J. Russell, and W. Powell. 2005. Isolation of high molecular weight DNA suitable for BAC library construction from woody perennial soft-fruit species. Biotechniques 38:69-71.

Horn, R., A. Lecouls, A. Callahan, A. Dandekar, L. Garay, P. McCord, W. Howad, H. Chan, I. Verde, D. Main, S. Jung, L. Georgi, S. Forrest, J. Mook, T. Zhebentyayeva, Y. Yu, H.R. Kim, C. Jesudurai, B. Sosinski, P. Arús, V. Baird, D. Parfitt, G. Reighard, R. Scorza, J. Tomkins, R. Wing, and A.G. Abbott. 2005. Candidate gene database and transcript map for peach, a model species for fruit trees. Theor. Appl. Genet. 110:1419-1428.

International Peach Genome Initiative. 2010. Phytozome v5.0: Peach genome (Prunus persica). 16 June 2010. <www.phytozome.org/peach>. 
Jáuregui, B., M.C. de Vicente, R. Messeguer, A. Felipe, A. Bonnet, G. Salesses, and P. Arus. 2001. A reciprocal translocation between 'Garfi' almond and 'Nemared' peach. Theor. Appl. Genet. 102: 1169-1176.

Joobeur, T., M.A. Viruel, M.C. de Vicente, B. Jauregui, J. Ballester, M.T. Dettori, I. Verde, M.J. Truco, R. Messeguer, I. Batlle, R. Quarta, E. Dirlewanger, and P. Arús. 1998. Construction of a saturated linkage map for Prunus using an almond $\times$ peach F-2 progeny. Theor. Appl. Genet. 97:1034-1041.

Jung, S., C. Jesudurai, M. Staton, Z. Du, S. Ficklin, I. Cho, A. Abbott, J. Tomkins, and D. Main. 2004. GDR (Genome Database for Rosaceae): Integrated web resources for Rosaceae genomics and genetics research. BMC Bioinformatics 5:130.

Kassim, A., J. Poette, A. Paterson, D. Zait, S. McCallum, M. Woodhead, K. Smith, C. Hackett, and J. Graham. 2009. Environmental and seasonal influences on red raspberry anthocyanin antioxidant contents and identification of QTL. Mol. Nutr. Food Res. 53:625-634.

Khaldi, N., J. Collemare, M.H. Lebrun, and K.H. Wolfe. 2008. Evidence for horizontal transfer of a secondary metabolite gene cluster between fungi. Genome Biol. 9:R18, doi: 10.1186/gb-2008-9-1-r18.

Kumar, A. and B.E. Ellis. 2003. 4-Coumarate:CoA ligase gene family in Rubus idaeus: cDNA structures, evolution and expression. Plant Mol. Biol. 31:327-340.

Lalli, D.A., V. Decroocq, A.V. Blenda, V. Schurdi-Levraud, L. Garay, O. LeGall, V. Damsteegt, G.L. Reighard, and A.G. Abbott. 2005. Identification and mapping of resistance gene analogs (RGAs) in Prunus: A resistance map for Prunus. Theor. Appl. Genet. 111:1504-1513.

Lin, Z., S. Zhong, and D. Grierson. 2009. Recent advances in ethylene research. J. Expt. Bot. 60:3311-3336.

McCallum, S., M. Woodhead, C.A. Hackett, A. Kassim, A. Paterson, and J. Graham. 2010. Genetic and environmental effects influencing fruit color and QTL analysis in raspberry. Theor. Appl. Genet., doi: 10.1007/s00122-010-1334-5.

Novakova, R., J. Bistakova, D. Homerova, B. Rezuchova, and J. Kormanec. 2002. Cloning and characterization of a polyketide synthase gene cluster involved in biosynthesis of a proposed angucycline-like polyketide auricin in Streptomyces aureofaciens CCM 3239. Gene 297:197-208.

Ogundiwin, E.A., C.P. Peace, T.M. Gradziel, D.E. Parfitt, F.A. Bliss, and C.H. Crisosto. 2009. A fruit quality gene map of Prunus. BMC Genomics 10:587.

Pattison, J.A., S.K. Samuelian, and C.A. Weber. 2007. Inheritance of Phytophthora root rot resistance in red raspberry, determined by generation means and molecular linkage analysis. Theor. Appl. Genet. 115:225-236.

Potter, D., S.M. Still, T. Grebenc, D. Ballian, G. Bozic, J. Franjiae, and H. Kraigher. 2006. Phylogenetic relationships in tribe Spiraeae (Rosaceae) inferred from nucleotide sequence data. Plant Syst. Evol. 266:105-118.

Qi, X., S. Bakht, M. Leggett, C. Maxwell, R. Melton, and A. Osbourn. 2004. A gene cluster for secondary metabolism in oat: Implications for the evolution of metabolic diversity in plants. Proc. Natl. Acad. Sci. USA 101:8233-8238.

Roberts, M.R. and G.L. de Bruxelles. 2002. Plant 14-3-3 protein families: Evidence for isoform-specific functions? Biochem. Soc. Trans. 30:373-378.

Rozen, S. and H. Skaletsky. 2000. Primer3 on the WWW for general users and for biologist programmers. Methods Mol. Biol. 132:365386.

Sargent, D.J., J. Clarke, D.W. Simpson, K.R. Tobutt, P. Arús, A. Monfort, S. Vilanova, B. Denoyes-Rothan, M. Rousseau, K.M. Folta, N.V. Bassil, and N.H. Battey. 2006. An enhanced microsatellite map of diploid Fragaria. Theor. Appl. Genet. 112:1349-1359.
Sargent, D.J., F. Fernandez-Fernandez, A. Rys, V.H. Knight, D.W. Simpson, and K.R. Tobutt. 2007a. Mapping of $A_{1}$ conferring resistance to the aphid Amphorophora idaei and $d w$ (dwarfing habit) in red raspberry (Rubus idaeus L.) using AFLP and microsatellite markers. BMC Plant Biol. 7:15, doi: 10.1186/1471-2229-7-15.

Sargent, D.J., A. Rys, S. Nier, D.W. Simpson, and K.R. Tobutt. 2007 b. The development and mapping of functional markers in Fragaria and their transferability and potential for mapping in other genera. Theor. Appl. Genet. 114:373-384.

Schaffer, R.J., E.N. Friel, E.J.F. Souleyre, K. Bolitho, K. Thodey, S. Ledger, J.H. Bowen, J.-H. Ma, B. Nain, D. Coen, A.P. Gleave, R.N. Crowhurst, B.J. Janssen, J.-L. Yao, and R.D. Newcomb. 2007. A genomics approach reveals that aroma production in apple is controlled by ethylene predominantly at the final step in each biosynthetic pathway. Plant Physiol. 144:1899-1912.

Serna, L. and C. Martin. 2006. Trichomes: Different regulatory networks lead to convergent structures. Trends Plant Sci. 11:274280.

Shepherd, T., N. Birch, C. Jorna, C. Mitchell, J. Cross, D. Hall, and D. Farman. 2009. Profiling of raspberry wound volatiles using a combination of SPME and GC-TOF-MS. Metabomeeting, Norwich, UK 58(July):111. (Abstr.).

Shulaev, V., A. Aharoni, A. Allan, P. Arús, T.-L. Ashman, N. Bassil, M. Borodovsky, P.D. Burns, O.R. Crasta, R. Crowhurst, J. Davik, T.M. Davis, A. Delcher, B. Denoyes-Rothan, A. Dickerman, A. Dhingra, C. Evans, S.A. Filichkin, O. Folkerts, J. Hancock, R. Hellens, S.H. Holt, P. Jaiswal, R. Jensen, S.S. Korban, A. Liston, A. Lomsadze, S.P. Mane, L. Meisel, T.P. Michael, R. Mittler, K. Mockaitis, T.C. Mockler, A. Monfort, H. Priest, J.J. Ruiz-Rojas, S. Salzberg, D.J. Sargent, W. Schwab, J. Setubal, H. Silva, J. Slovin, R. Veilleux, R. Velasco, R. Viola, and K.M. Folta. 2010. Full genome sequencing of the woodland strawberry, Fragaria vesca. Plant and Animal Genomes XVIII Conference 249 (Abstr.). 16 June 2010. <http://www.intl-pag. org/18/abstracts/W32_PAGXVIII_249.html>.

Shulaev, V., S.S. Korban, B. Sosinski, A.G. Abbott, H.S. Aldwinckle, K.M. Folta, A. Iezzoni, D. Main, P. Arús, A.M. Dandekar, K. Lewers, S.K. Brown, T.M. Davis, S.E. Gardiner, D. Potter, and R.E. Veilleux. 2008. Multiple models for Rosaceae genomics. Plant Physiol. 147:985-1003.

Van Ooijen, J.W. and R.E. Voorrips. 2001. JoinMap ${ }^{\circledR}$ 3.0: Software for the calculation of genetic linkage maps. Plant Research International, Wageningen, The Netherlands.

Vilanova, S., D.J. Sargent, P. Arús, and A. Monfort. 2008. Synteny conservation between two distantly related Rosaceae genomes: Prunus (the stone fruits) and Fragaria (the strawberry). BMC Plant Biol. 8:67.

Woodhead, M., J. Russell, J. Squirrell, M. Hollingsworth, L. Cardle, L. Ramsay, M. Gibby, and W. Powell. 2003. Development of ESTSSRs from the alpine lady-fern, Athyrium distentifolium. Mol. Ecol. Notes 3:287-290.

Woodhead, M., K. Smith, S. Williamson, L. Cardle, L. Mazzitelli, and J. Graham. 2008. Identification, characterisation and mapping of simple sequence repeat (SSR) markers from raspberry root and bud ESTs. Mol. Breed. 22:555-563.

Zhebentyayeva, T.N., G. Swire-Clark, L.L. Georgi, L. Garay, S. Jung, S. Forrest, A.V. Blenda, B. Blackmon, J. Mook, R. Horn, W. Howad, P. Arús, D. Main, J.P. Tomkins, B. Sosinski, W.V. Baird, G.L. Reighard, and A.G. Abbott. 2008. A framework physical map for peach, a model Rosaceae species. Tree Genet. Genomes 4:745-756.

Zheng, D. and G. Hrazdina. 2008. Molecular and biochemical characterization of benzalacetone synthase and chalcone synthase genes and their proteins from raspberry (Rubus idaeus L.). Arch. Biochem. Biophys. 470:139-145. 